Sign Systems Studies 49(1/2), 2021, 132-165

\title{
Towards an integration of two aspects of semiosis - A cognitive semiotic perspective
}

\author{
Piotr Konderak ${ }^{1}$
}

\begin{abstract}
Meaning-making processes, understood hierarchically, in line with the Semiotic Hierarchy framework, change on various timescales. To account for and predict these changes, one can take a cognitive view on semiosis. I adopt an interdisciplinary approach combining semiotic studies and cognitive studies in an attempt to account for meaning-making activity and to predict the course of semiosis. In this context, I consider meaning-making activity as shaped by both "external" (to a semiotic system) as well as "internal" factors. I also show how both the "external" and "internal" sources of the dynamicity of meaning-making should be framed in terms of studies on cognition.

I start with a non-standard, $4 \mathrm{e}$ approach to meaning-making. According to this framework, meaning-making processes are constituted by (and not just dependent on) environmental and bodily factors. The dynamicity of semiosis can be accounted for in terms of an experiencing, embodied subject (agent) enacting her/his/its own domain of meaningful phenomena. As I argue, this perspective on meaning-making is the cognitive foundation of the first two levels of the Semiotic Hierarchy.

In the following sections I present the Peircean view on signs and semiosis, according to which semiosis is a result of the very nature of a sign and a sign system. In this view, the dynamicity of semiosis has primarily "internal" sources: it stems from the unavoidable fallibility of interpretation and synechism of signs. As I show, this aspect of semiosis can be addressed by means of standard (cognitivist) cognitive science and by means of cognitive modelling.

Ultimately, I sketch a proposal of an attempt to develop a uniform cognitive framework allowing for integration of the above-mentioned aspects of semiosis - a framework based on Rowlands' idea of the Amalgamated Mind.
\end{abstract}

Keywords: cognitive semiotics; meaning-making; cognitivism; enactivism; embodiment; the Amalgamated Mind approach; Peircean semiotics

1 Department of Logic and Cognitive Science, Maria Curie-Sklodowska University in Lublin, Pl. Marii Curie-Sklodowskiej 4, Room 205, 20-031 Lublin, Poland; e-mail: piotr.konderak@ umcs.pl. 


\section{Introduction: Cognition and semiosis}

There is a deep interdependence between cognition and meaning-making activities (semiosis, understood broadly). In one of my earlier papers I argued that "semiotic processes are, in fact, cognitive processes. For now, I leave open the question of whether all semiotic processes are cognitive processes, or only some of them. Even if only some of them are cognitive, we can still gain knowledge about the nature of semiosis by studying appropriate cognitive activities" (Konderak 2016: 85). I do not intend, however, to suggest the replacement of semiotics by cognitive science(s) (cf. Nöth 1994: 5). Instead, it seems that semiotics and cognitive science provide different perspectives on the phenomenon of meaning-making. Such an observation is important, as it suggests that the methods of cognitive science may contribute to previous explanations and predictions of meaning-making activities. This idea is not new - it is present in numerous views on the mutual relationship between semiotics and cognitive sciences. Thomas Daddesio (1995: 2) proposes "a cognitive theory of symbols" and opts for "a cognitive approach to semiosis" (Daddesio 1995: 10). Jerzy Pelc (2013) argues for the rapprochement of studies on cognition and communication on the one hand, and semiosis on the other hand. Umberto Eco (1999) declares that "it does not displease me that semiotics has come to be included in this confederation [of cognitive sciences], independently of the question (still debated) whether semiotics is a cognitive science or cognitive sciences are a branch of semiotics."

However, the claim about a mutual relationship between cognitive structures and processes and meaning-making activities and - consequently - the postulated interdependence of cognitive science and semiotics raises several questions. First, the term 'cognitive science' is nowadays used in reference to a number of relatively incompatible approaches. On the one hand, the term covers so-called cognitivism, a computational approach to cognitive activities. Such a view on cognition emphasizes the role of representations (in their symbolic and subsymbolic forms) as well as operations on representations in accounts of cognition. On the other hand, the so-called 4e (enactive, embodied, embedded, extended) approaches to mind and cognition (Varela, Thompson, Rosch 1991; Thompson 2007; Rowlands 2010) gain their importance in discussions on the nature and key features of cognitive activities. Such a line of thinking about cognition not only stresses the role of dynamic interactions between an embodied subject and her/his/its environment, but even treats the two elements (a subject and his/her/its body, an environment) as one coupled dynamic system (Van Gelder 1995). This paper addresses the question of

2 Eco, Umberto 1999. Semiotics in the Next Millennium. Retrieved from http://www.umbertoeco.it/ CV/Semiotics\%20in\%20the\%20next\%20millennium.pdf. 
the putative roles of these two lines of thinking about cognition in accounting for meaning-making activities and in predicting the behaviour of semiotic systems.

Second, the term 'semiosis' (or 'meaning-making') is equivocal as well. Semioticians discuss meaning-making in the context of various semiotic theories (Stoics', Peircean, etc., semiotics), locating their research within various branches of semiotics (biosemiotics, semiotics of culture, etc.). The multiplicity of approaches and schools perplexes cognitive scientists and makes the combination of semioticcognitive studies somewhat difficult.

The situation has given rise to the emergence of a new discipline: cognitive semiotics. Cognitive semiotics was initially seen as a discipline combining research in semiotics and in cognitive science. As a consciously developed discipline, cognitive semiotics focuses on the phenomenon of meaning and meaning-making processes as well as on models of cognitive processes responsible for meaningmaking activities. Such a combination was supposed to overcome the limitations of each of these two disciplines (Sonesson 2009: 35).

To understand the subject matter of cognitive semiotics, the reader has to realize that the meaning of the term 'semiotics' in the name of the discipline has been significantly broadened. Cognitive semioticians focus on meanings and meaningmaking in general and define semiotics accordingly. Signs are considered just a sub-class of all possible meaningful phenomena; the usage and interpretation of signs are just one of the possible kinds of meaning-making activity. In line with these considerations, Lorraine McCune (2016: 127) writes: "Under [the extended definition of semiotics], favoured by many in cognitive semiotics, all experience of meaning (even sensation) can be considered semiotic (i.e. meaningful), but only some special kinds of meanings are signs."

In the present paper, I take a cognitive semiotic view on meaning-making (semiosis). In particular, I adopt the Semiotic Hierarchy framework as an attempt to unify studies on various forms of meaning-making. In this context, I consider meaning-making activity as shaped by both "external" (bodily-environmental) as well as "internal" (to a semiotic system; "intra-systemic") factors. I also show how these two sources of the dynamicity of meaning-making ("external" and "internal") should be framed in terms of contemporary studies on cognition. The "internal" dynamicity of semiosis is illustrated by means of a computational-cognitivist model of semiosis which draws on the Peircean theory of signs according to which the interaction of Firstness, Secondness and Thirdness constitutes the dynamicity of semiosis.

Recognizing the incompleteness and limitedness of the cognitivist account of meaning-making, I introduce aspects of the so-called 4e approach to cognition and meaning-making and discuss its contribution to the explanations of semiosis. In particular, the notions of embodiment, embeddedness, consciousness and 
agency are elaborated. I also argue that such an approach complements thirdperson methods delivered by cognitivism.

Finally, trying to efface a kind of bifurcation between cognitivism and 4e approaches, I present Mark Rowlands' Amalgamated Mind view on cognition (and meaning-making). This approach seems promising as an attempt to combine the cognitivist-representational view on cognition and the 4e approach to sense-making.

At this juncture, one caveat concerning the terminology used is necessary. The "internal"/"external" distinction is ambiguous. ${ }^{3}$ Philosophy of mind, sciences of mind, social and cultural studies define this distinction in various ways. The understanding of these terms for the purposes of my paper is motivated by Ludwig von Bertalanffy's General Systems Theory (Bertalanffy 1968). I start with the notion of a semiotic system as proposed by James Fetzer (cf. Section 4, below). Fetzer's notion of a semiotic system is, in turn, interpreted in terms of Peircean semiosis. Consequently, the dynamicity of semiosis arises from the unavoidable fallibility of interpretation and synechism of signs (and is reflected by the phenomenon of unlimited semiosis). The factors responsible for such dynamicity are internal to a semiotic system, i.e. they reflect the very nature of the sign. ${ }^{4}$ However, the dynamicity of meaning-making at the first two levels of the Semiotic Hierarchy is a result of interactions of a semiotic system with its umwelt and Lifeworld. Accordingly, relevant aspects of the environment are considered "external" in reference to a semiotic system ("extra-systemic").

\section{The problem of semiotic levels and the Semiotic Hierarchy framework}

The above considerations on the relationship between semiosis (broadly understood as meaning-making) and cognition gave rise to a multiplicity of cognitive semiotic approaches. ${ }^{5}$ What is common to all these views is an attempt to characterize dynamic meaning-making processes in their variety and diversity. As I have

3 Heil (2004: 421) characterizes the situation in the following way: "The distinction is intuitively clear, but difficult to articulate precisely. This suggests, not that the distinction is hazy, but that it is a fundamental distinction, one for which we should be hard pressed to explicate in simpler, more familiar terms."

4 Perhaps the Saussurian view on the nature of a system of (linguistic) signs is an even better illustration of internal or "intra-systemic" factors - see Saussure 1959.

5 The first anthology in cognitive semiotics (Zlatev, Sonesson, Konderak 2016) provides a decent overview of the multiplicity of approaches within cognitive semiotics. 
discussed elsewhere (Konderak 2018), there is quite a broad scope of phenomena which may be treated as instances of meaning-making activities: self-sustaining, autopoietic activities, emotional, pre-reflexive responses to bodily states, imitation and pantomime, language-based activities, to name some. In this context, the question of the scope and characteristic features of semiosis becomes important. Accordingly, there are a number of attempts to delimit the scope of a "semiotic territory", identify levels of semiosis, the boundaries of these levels, semiotic thresholds (e.g. Nöth 2001; Stjernfelt 2003; Alrøe 2016; Rodríguez Higuera, Kull 2017) or semiotic zones (Kull 2009). In particular, the problem of the lower semiotic threshold, i.e. "precise conditions for semiosis to appear" (Kull 2009: 9) is discussed. This threshold may be located relatively high, stressing the arbitrariness of signs, as in case of Eco's semiotics (Eco 1976). However, as Nöth (2000) notices, the threshold is consequently lowered and allows us to embrace animal meaningmaking (e.g. Sebeok 1963), meaning-making in plants (e.g. Krampen 1981) or meaning-making at the level of the "prebiological world", as in physicosemiotics (Koch 1987) or physiosemiotics (Deely 2001; cf. also Nöth 2001: 14-15).

These discussions on the lower semiotic threshold are followed by developments of the levels of semiosis and subsequent semiotic thresholds. Kull (2009), for instance, develops the idea of primary, secondary and tertiary semiotic threshold zones separating non-semiotic systems, on the one hand, and vegetative, animal and cultural semiotic systems, on the other hand. Despite some similarities between the abovementioned attempts to specify levels of semiosis, there are important differences between them and discussions on the topic continue. As many semioticians agree, the specification of such thresholds cannot be a result of theoretical - narrowly semiotic - inquiries alone. Such thresholds should reflect the results of studies in cognitive sciences, psychology, neuroscience, biology, physics and other related areas. As Kull (2009: 16) stresses: “The only way to find these thresholds is on the basis of a combination of semiotic modelling and empirical studies."

The above problems are addressed by Jordan Zlatev in his attempt to provide a common framework for various meaning-making phenomena in the so-called Semiotic Hierarchy (Zlatev 2009, 2018). ${ }^{6}$ In his response to the semiotic thresholds problem, Zlatev develops an interdisciplinary and integrative hierarchy of semiotic levels. In this approach, subsequent levels are motivated by phenomenological, developmental and evolutionary factors.

6 In my paper I refer to the earlier version of the Semiotic Hierarchy framework (Zlatev 2009). The additional distinction introduced in 2018 does not have any effect on my argumentation. 
The Semiotic Hierarchy in its original incarnation distinguishes the four levels of meaning: life, consciousness, sign function and language (Zlatev 2009: 169). All these levels share the following characteristic: there is a subject immersed or embedded in an environment. Such a subject is related to his/her/its environment by means of a system of values. The system of values influences (sometimes even determines) interactions between the subject and the environment. The above formulation strongly suggests that meaning-making activity cannot be limited either to internal processes, immanent to a subject, or to phenomena in the environment in which the subject is embedded. Rather, meaning-making is a relational phenomenon that consists in value-based interactions between a subject and its "world".

The lowest level of the Semiotic Hierarchy (the level of life) is an expression of the conviction that all living creatures (and only such creatures) are capable of meaning-making. ${ }^{7}$ According to this view, "living is a process of cognition" (Maturana 1970) and "living is sense-making" (Varela, Thompson, Rosch 1991; Thompson 2007: 157). An organism, such as the bacterium E. coli (Thompson 2007; Thompson, Stapleton 2009) or a tick (Uexküll 1982; Sonesson 2007: 101108 ), which is able to regulate its behaviour in response to environmental features is an instantiation of a meaning-making organism at the first level. Meaningful aspects of an organism's environment form an umwelt (Uexküll 1957). The umwelt is understood here as a part of an organism's environment detected by a system of biological values. In this respect, Zlatev agrees with semioticians arguing "for the lower semiotic threshold at the boundary of life" (Kull 2009: 11).

The emergence of consciousness, in particular in its phenomenal form, is the basis of the second level of meaning, namely the phenomenal meaning. A subject at the second level is an experiencing subject, which is intentionally directed towards experienced objects. The world in which a subject is embedded changes: it is no longer just the umwelt, a world of biologically meaningful phenomena, but the Lifeworld - a world of phenomena given in experience. As Zlatev states, the phenomenal value system picks up elements of our environment which are experienced in one or the other way. The subject not only proceeds in a certain direction to benefit biological conditions, it (he, she) also experiences these conditions. An octopus may proceed towards warmer or colder regions, but it may also experience warmness or coldness (and pleasure or suffering, etc.). To put it simply, 'meaningful' means 'consciously experienced'.

7 The formulation is reminiscent of Thomas Sebeok's view on semiosis as the "criterial attribute of life" (Sebeok 1986: 73). As mentioned in the introduction, meaning-making at the level of life is not tantamount to sign-usage. Consequently - in contraposition to biosemiotics approaches - the first level involves semiosis but not signs. 
The dynamicity of meaning-making at these two levels seems to be driven primarily by external factors in reference to a meaning-making subject. In other words, explanations and predictions of meaning-making processes supervene on e.g. ontogenetic, evolutionary factors (cf. Donald 1991). As a result, cognitive accounts of meaning-making should be able to address the role of environmental factors as well as bodily ones in meaning-making activities. As I claim, it is a version of an enactive-embodied-embedded-extended view on cognition which can address the role of "external" or "extra-systemic" factors.

Consciousness is necessary, but insufficient for the next level of meaning, namely the proper semiotic level or the level of signs. The third level of meaning appears when a conscious subject is capable of the symbolic or semiotic function (in the sense of Piaget 1962). Most notably, the subject is able to differentiate between the sign itself (in any form: either a gesture, a picture or a symbol) and what it represents. The ability to relate the two phenomena: expression and its content on the basis of one of the grounding relations and the ability to learn and re-use learned signs is necessary as well. The third level is characterized by a signification value system. In other words, selected phenomena are meaningful to the subject on the basis of the semiotic relationship between a sign and its content or referent, namely proximity (in the case of indexes), similarity of a kind (in the case of icons) or conventionality (in the case of symbols).

The fourth level, the level of linguistic meaning, requires a subject which strives to use conventional symbols in the correct way, according to a set of norms. The natural and cultural Lifeworld in which the linguistic self is embedded is complemented by "the universe of discourse" (Zlatev 2009: 185). In other words, the subject is immersed in the world of everyday conversations, novels, poems, myths, scientific theories and other spoken or written "texts". ${ }^{8}$ The representational character of language is - in turn - a heritage of the third level, where - as mentioned above - the differentiation between a sign and the object represented appears.

There are two emergent properties at the level of language, namely normativity and systematicity. According to the Semiotic Hierarchy, linguistic conventions are normative, which means that some uses of language utterances are considered

8 The idea is clearly present in Lotman's works; in particular, it is reflected in his concept of the semiosphere as "that same semiotic space, outside of which semiosis itself cannot exist" (Lotman 2005: 208). Lotman's (2005: 206) remark about "a specific semiotic continuum, which is filled with multi-variant semiotic models situated at a range of hierarchical levels" can be related to Zlatev's idea of the Semiotic Hierarchy. Such an impression is strengthened by Lotman's remarks on the relationship between the semiosphere and umwelten and culture (cf. Kull 2005; Semenenko 2012). As Semenenko suggests, in this sense we may treat Lotman as a precursor of the cognitive semiotic approach to meaning-making. 
correct and others are considered incorrect (cf. Itkonen 2003). Language is necessarily a system - a system functioning at the level of grammar as well as at the level of meanings. Signs (the third level) may form a system as well, but it is not a necessary feature.

The third and fourth levels share two features: they develop as systems of signs and they are representational. The systemic nature of meaning-making at the levels of signs and language gives rise to "internal", intra-systemic dynamicity - as stressed by e.g. Charles S. Peirce, "it is a fundamental mistake to suppose that an idea which stands isolated can be otherwise than perfectly blind" (CP 4.71). In addition, meaning-making should be explained in terms of representational states and operations on such states. As I argue below, both features of meaning-making can be accounted for in terms of the cognitivist view on cognition by means of cognitivist models.

It must be stressed that the higher levels in the Semiotic Hierarchy do not replace lower ones. In other words, although higher levels are not reducible to lower ones, the former at the same time depend on the latter for their existence. ${ }^{9}$ Subjects capable of meaning-making at higher levels are also capable of meaningmaking at lower levels (but not vice versa). This feature reflects the situation in which I, as an adult meaning-making subject, can understand the linguistic label 'save', but in its absence I can make sense of an iconic representation of a diskette.

\section{4e accounts of semiosis: sense-making}

It could be said that it is the neo-Cartesian view on cognition and meaning-making activities which sees semiosis as a purely internal, intra-systemic process. This point of view is clearly reflected in interpretations of semiotics as a kind of logical calculus. ${ }^{10}$ Such a perspective on semiosis - as I argue - is reflected in the cognitivist view on meaning-making (cf. Section 6, below). However, the Semiotic Hierarchy framework and the so-called non-standard cognitive science reject the Cartesian point of departure, namely the conviction that cognition (and meaningmaking) is primarily an internal activity. The anti-Cartesian attitude is reflected in claims about the primacy of studies on meaning-making as embodied interactions with an environment. To put it differently: meaning-making is initially both an

9 In his most recent version of the Semiotic Hierarchy, Zlatev (2018: 5) invokes MerleauPonty's notion of Fundierung as describing the relationship between the levels.

10 This approach seems to be particularly influential in the Polish semiotic tradition, stemming from the Lwów-Warsaw school of philosophy. As Kull (2009: 16) writes: "Semiotics is logic - so understood already by both John Locke and Charles Peirce." 
internal and an external process and semiosis is constituted by external and internal factors. Accepting the "lower semiotic threshold" at the level of life, we cannot reduce meaning-making to internal, rule-based operations on representations, or to constant overcoming fallibilism of interpretations by means of subsequent reinterpretations.

The above assumptions are reflected in the Semiotic Hierarchy framework. Living creatures, for instance, make sense of their surroundings transforming them into an umwelt (Uexküll 1957). At the first level of the Semiotic Hierarchy, meaning-making activity crucially involves a subject (here: an organism) acting in an environment (here: the physical-biological world) on the basis of the specific value system (here: biological mechanisms which are responsible for the preservation and reproduction of life and, in particular, for self-organization). Meaningmaking consists of such interactions. Neutral (from the point of view of the survival of an organism) environmental factors are meaningless for the organism.

A meaning-making subject at the second level of the Semiotic Hierarchy is an experiencing, conscious subject which is intentionally directed towards objects of consciousness. Such a subject is not enclosed in his/her own mentality, but is immersed in a Lifeworld, a world of phenomena given in experience. Meaningmaking may also be characterized as a disclosing activity, where intentional acts reveal the object in the world as having certain aspects. Once again, the relationship between an experiencing subject and his/her/its Lifeworld gives rise to meaning. My claim is that it is an enactive-embodied view on cognition and meaning-making which can provide a basis for explanations and predictions of the abovementioned phenomena.

Enactivism, which is expected to be a replacement of both cognitivism and connectionism (cf. Thompson 2007) addresses the problem of a cognitive approach to meaning-making activity [Evan Thompson and Mog Stapleton (2009) use the term 'sense-making' in this context]. Moreover, the very idea of cognition, as consisting of a dynamic interaction of a subject and his/her/its environment, seems to be consistent with the basic assumptions of cognitive semiotics. ${ }^{11}$ Cognitive semioticians favouring enactive-embodied approaches to cognition claim that a notion of a subject, as an active information-seeking creature, as an organism co-creating its Lifeworld in perception and actions, provides relevant tools for the analysis of meaning.

11 In fact, some cognitive semioticians suggest that reference to enactive cognitive science is an indispensable feature of the cognitive semiotic enterprise (Zlatev 2011; Pérez 2016; Tønnessen 2016). 
The enactive approach emerged as a counterproposal to the Cartesian view on mind and standard (Cartesian) cognitive science. As a result, the status of the enactive approach is special - it seems to embrace, to a degree, the embodiment and embeddedness of mind. What are the consequences of accepting "the deep continuity of life and mind" (Thompson 2007: ix) for accounts of meaningmaking?

Meaning-making at the first two levels of the Semiotic Hierarchy (life, consciousness) crucially requires dynamic interaction between a subject and its environment. This statement draws attention to (at least) three phenomena: the dynamicity of the meaning-making processes, the agency of a meaning-making entity and the embodied nature of such interactions. These three factors seem to be crucial for explanations of meaning-making activities. In Thompson's (2007: 13) own words, "the first idea is that living beings are autonomous agents that actively generate and maintain themselves, and thereby also enact or bring forth their own cognitive domains". Meaning-making subjects are not passive agents waiting for incoming stimuli and processing them according to a set of rules, but rather they are active information-seekers, acting in their environments. This aspect is emphasized by James J. Gibson (1979) in his ecological account of perception. Dynamicity - as an important aspect of sense-making - is also raised by researchers like Thompson, Ezequiel Di Paolo, Tom Froese and others (cf. De Jesus 2016: 130). As a result, environmental factors become a part of the meaning-making process, not just the source of internalized stimuli.

An environment becomes "a place of salience" due to the activity of an agent. ${ }^{12}$ As Thompson and Stapleton (2009: 25) summarize it, "even the simplest organisms regulate their interactions with the world in such a way that they transform the world into a place of salience, meaning and value into an [...] umwelt". Although agency seems to be crucial to meaning-making at the first two levels of the Semiotic Hierarchy, there is no clear-cut definition of agency: even though all the major enactivists refer to some notion of an agent, there is no consensus on the common characteristics of a meaning-making agent. According to Morten Tønnessen (2016: 69), agency may require "goal-directedness, self-governed activity, processing of semiosis and choice of action". What is important in the context of the present paper is that the enactivist view on agency is much richer than the cognitivist approach: the capacity to act on symbols according to sets of rules is

12 Notice here the difference in terminology: an agent (in the case of enactivism) and a subject (in the case of the Semiotic Hierarchy) reflect the differences in perspectives on meaningmaking. The term 'subject' seems to highlight the subjectivity of an acting entity, which is reflected in consciousness. The term 'agent', in turn, seems to highlight the very fact of the (inter)action, regardless of the putative experiential aspect of the interaction. 
supplemented by autonomous selfhood, purposiveness, a sense of ownership or a sense of agency (Gallagher 2007; Thompson 2007). Regardless of the definition of agency adopted, one issue seems to be clear: meaning-making systems actively "transform environments into inherently meaningful places of value and significance for the system itself” (De Jesus 2016: 132; cf also Thompson 2007). In Thompson's words, such a system "enacts" or "brings forth" its "own world of meaning and significance" (Thompson 2007: 13).

In the context of the cognitive semiotic approach to meaning-making, Tønnessen's distinction between quasi-subjects and proper subjects (Tønnessen 2016; Tønnessen, Beever 2014) seems to be particularly important. Both quasi-subjects and proper subjects can be treated as semiotic agents; the difference between them reflects the difference between agents at the first level of the Semiotic Hierarchy and agents at the second level. Quasi-subjects - living entities with "quasi-experience" - are capable of purposeful, goal-directed actions in their environments (cf. e.g. Cameron 2001: 456). In the case of proper subjects, we should also take into account the phenomenal dimension: they have "cohesive, integrated experience" (Tønnessen 2016: 81). ${ }^{13}$

As stressed above, in discussions on meaning-making at the second level of the Semiotic Hierarchy a phenomenological dimension of agency should be taken into account. In other words, functional/organizational properties, although necessary, are not sufficient for an adequate understanding of meaning-making systems. Within the phenomenological tradition it is Maurice Merleau-Ponty who particularly stresses the embodied character of experience; experience (especially self-experience) is not just the result of the workings of a disembodied mind; the body is involved in the very possibility of experience. In other words, the body (lived body, Leib) is an indispensable element of an experiencing subject.

The subject's or agent's body is intertwined ("coupled") with an environment in a two-way relationship. On the one hand, our environment constantly influences and regulates our bodies - as Shaun Gallagher and Dan Zahavi (2008) formulate it, our body in this sense reflects our environment. On the other hand, our body dynamically influences our environment. In consequence, there is a continuous dynamic interdependence. Enactive cognitive science particularly stresses the aspect of our functioning in the world. To sum up, the body - according to phenomenologists - cannot be adequately defined outside of the world, as it is already in the world. And as one cannot separate the mind and the body, one should not

13 It is possible that reference to enactive-embodied views on cognition would not be sufficient. As Tønnessen (2016) notices, it is possible that a wider, biosemiotic view on agency may be more adequate in the context of semiosis (interpreted in this paper as meaning-making). 
separate the body and the environment on which the body acts in considerations on meaning-making processes.

I focus on the two components of the $4 \mathrm{e}$ cognitive science, as they address - it seems - the most crucial aspects of meaning-making activity. The role of extended and embedded approaches is far less clear and less obvious.

The status of the extended view on cognition is equivocal. On the one hand, it can be treated as a consequence of extended functionalism (cf. Clark, Chalmers 1998). On the other hand, some interpretations of the extended view on cognition can be squared with embodied and embedded approaches. The extended approach to meaning-making states that one cannot enclose meaning-making in the skull (or even in the whole body). Any real meaning-making system is a coupled system (in Van Gelder's sense; cf. also Konderak 2018: 185-190) interacting with her/his/its environment. In such a system all the elements should have a causal role in the system, with both internal and external factors influencing or even governing the system's behaviour. Consequently, the elimination of the external factor results in a drop in performance. As Clark (2008: x) says, "when parts of the environment are coupled to the brain in the right way, they become part of the mind". The above features seem to support enactive and embodied views on meaning-making activities. In particular, the role of brain-body-environment interactions is stressed in the extended view. In other words, meaning-making activity goes beyond the skull and unifies the three elements. Cognitive semiotics would also accept the ideas of extra-neural information-bearers or extended representations. For instance, researchers who stress the role of mimesis as a form of representation necessary to achieve the level of language see it as a form of (embodied) representation. Language, contrary to Chomsky's tradition, can be analysed in terms of external phenomenon augmenting human cognition (Clark 1998). In the context of language, cognitive semioticians clearly appreciate the possibility of the discussion on distributed meaning-making systems. Specifically, the level of language (as a social phenomenon) in the Semiotic Hierarchy may require reference to extended cognitive systems.

However, the extended view also formulates claims which are difficult to square with enactive-embodied claims. In particular, it is difficult to combine the notion of agency - as discussed above - with the floating character of extended systems. It seems that the notion of an individual, persisting meaning-making subject is necessary for explanations of meaning. In addition, the functionalist leanings of the extended mind theory may be questioned by some cognitive semioticians stressing the role of phenomenal experience. Specifically, cognitive semioticians would tend to reject an extended interpretation of the body as just an instrument (or tool) of cognition. Additionally, the functionalist reading of the 
extended mind theory allows for the inclusion of artificial systems in the group of meaning-making creatures. This movement raises serious doubts. In summary, it seems that if the extended approach to cognition is to be used as a cognitive basis of meaning-making, it would require significant revisions; the present version can be incorporated in studies on meaning-making in some limited form.

The claim about the embedded character of cognitive processes and meaningmaking can be interpreted as a weaker version of the extended mind thesis. The extended mind crucially involves the constitution of cognitive processes of both neural and external factors. The embeddedness of cognitive processes means that environmental factors just enable, causally influence, or drive these processes. Embeddedness, in reference to perception, for instance, may mean that perceptual processes work only in the context of certain environmental circumstances. In this sense, light is a necessary factor enabling vision. Interpreted in this way, embeddedness does not contribute crucially to the discussion on the cognitive foundations of meaning-making. Such claims are accepted both by $4 \mathrm{e}$ cognitive scientists and computationalist cognitivists.

In spite of the usefulness of the 4e approach to meaning-making in the respect presented above, $4 \mathrm{e}$ cognitive science cannot address one crucial feature of meaning-making at the third (and fourth) levels, namely the representational nature of signs. The anti-representational attitude presented by initiators of enactivism (Varela, Thompson, Rosch 1991) as well as some contemporary contributors (Hutto, Myin 2012) is at odds with the notion of a sign and sign-mediated meaning. ${ }^{14}$ Zlatev (2011) writes that "the classical phenomenological distinction between presentation and representation needs to be respected and theoretically addressed" ${ }^{15}$

\section{Bridging the gap between levels: On the emergence of the capacity to represent}

As stressed above, the specification of semiotic levels and thresholds should be justified by empirical findings. A number of relevant studies are devoted to the question of the emergence of the capacity for using signs. In particular, the

14 Hutto and Myin's anti-representationalism is somehow limited. Their radical enactivism refers only to basic minds, leaving more complex, enculturated, semiotic or linguistic minds aside. As the authors admit, "some cognitive activity - plausibly, that associated with and dependent upon the mastery of language - surely involves content" (Hutto, Myin 2012: xviii). 15 Zlatev, Jordan 2011. What is cognitive semiotics? SemiotiX, XN-6 was retrieved from https:/semioticon.com/semiotix/2011/10/what-is-cognitive-semiotics/. 
problem has been extensively presented by three researchers, the "informal founding fathers" of cognitive semiotics, Merlin Donald (1991), Terrence Deacon (1997) and Michael Tomasello (2008), from both evolutionary and ontogenetic perspectives. Each of them attempted to indicate the putative crucial factor responsible for the emergence of semiotic capacities, namely: mimesis (Donald), the capacity for symbolic representation (Deacon) and understanding communicative intentions (Tomasello). Donald's idea of mimesis as the "missing link" is of particular importance here. Donald (1991: 168) defines mimesis in the following way: "Mimetic skills or mimesis rests on the ability to produce conscious, self-initiated, representational acts that are intentional, but not linguistic". In other words, mimetic creatures deliberately use their bodies for representational means. To show the transition between the level of conscious meaning-making and sign-using, Zlatev (2007: 318-320) elaborates Donald's notion of mimesis. Mimetic skills, according to Zlatev's elaboration, evolved in time. The simplest form preceding mimesis is called "proto-mimesis" and is based on cross-modal mappings between perception and proprioception. Proto-mimetic behaviour (e.g. neonatal imitation) is involuntary, devoid of conscious control. Conscious control over bodily movements starts the new level of mimesis. However, the crucial moment for the transition between consciousness and sign-level is when a voluntary bodily movement corresponds (e.g. indexically - in the case of, e.g. pointing, or iconically - in the case of pantomime) to some object, action or event. Actions under conscious control, corresponding to some phenomenon and differentiated from it, constitute the socalled dyadic mimesis. The next, third stage (triadic mimesis) refers to an intentional communication: bodily movements are intended to stand for some object or action - consequently, there is an addressee for the actions. Triadic mimesis is instantiated in the form of pointing and pantomime.

In terms of cognitive studies, embodied interactions with an environment give rise to representational capacities. Coupled interactions between an organism and an environment (the first level) result in proto-mimesis in the sense presented above. Embodiment, in turn, gives rise to the experiential aspect of meaningmaking activities (Merleau-Ponty 1962). Both reflect enactive and embodied assumptions.

\section{On the Peircean view on meaning-making}

Addressing the cognitive semiotic problem of the relationship between meaning-making (semiosis) and cognition, I refer to an interpretation of Peircean philosophy and semiotics as a promising starting point. The Peircean account 
of meaning-making seems to refer to the third and fourth levels of the Semiotic Hierarchy. As Peirce notes, the acts of consciousness by themselves - in contraposition to René Descartes - cannot be considered meaningful thoughts. Instead, a meaningful thought must be captured in the form of signs: "The only thought, then, which can possibly be cognised is thought in signs. But thought which cannot be cognised does not exist. All thought, therefore, must necessarily be in signs" (CP 5.251); "All thought is in signs" (CP 2.213); "we think only in signs" (CP 2.302). These statements suggest that at least some cognitive processes (here called 'thinking') are also semiotic activities; therefore, it seems that by studying cognition we can elicit some of the properties of semiotic structures and processes.

Semiotics is defined by Peirce as "the doctrine of the essential nature and fundamental varieties of possible semiosis" (CP 5.488). Semiosis, in turn, is characterized in the following way: "But by 'semiosis' I mean, on the contrary, an action, or influence, which is, or involves, a cooperation of three subjects, such as a sign, its object, and its interpretant, this tri-relative influence not being in any way resolvable into actions between pairs" (CP 5.484).

To clarify the above statements and quotations and to prepare a ground for a computational model of semiosis presented in the following section, I present a brief summary of the Peircean approach.

The Peircean notion of a sign necessarily involves a triadic structure: it is the unity of a representamen, an object and an interpretant. The representamen - the first element of the triadic relation - is used in the definition as a sign-vehicle, i.e. as a form the sign takes. The representamen represents some object (the second element of the triadic relationship). The representamen requires a mental interpretant, "cognition of a mind" (CP 2.242). In other words, the representamen exerts an effect on the mind of an (human) interpreter. This third element, the interpretant is presented as the sense made of the sign. The interpretant of the sign is the translation of the original sign into other signs: "the meaning of a sign is the sign it has to be translated into" (CP 4.132). Such a translation constitutes a new, more developed sign which, in turn, leads to better understanding of the sign's object. Peircean semiosis crucially involves a system of internal representations: "A sign, or representamen, is something which stands to somebody for something in some respect or capacity. [...] [I]t stands for that object, not in all respects, but in reference to a sort of idea, which I have sometimes called the ground of the representamen" (CP 2.228, original italics). The main function of a representamen is to represent an object to some mind. Such representation does not provide the complete characteristics of this object, but only an aspect of it. Peirce refers to the three elements enumerated above in terms of (respectively): Firstness, Secondness and Thirdness. Accordingly, semiosis is to be understood as the interaction between 
Firstness, Secondness and Thirdness (within the sign) and as the process of constant interpretation of a sign by means of other signs (within the sign system). These statements suggest that all meaning-making by means of signs is dynamical in nature, it is a process. This process - in the Peircean view - crucially involves the three semiotic functions: representation, mediation and interpretation.

There are two crucial features of the meaning-making processes: fallibilism and synechism of semiosis. Fallibilism means that each interpretation - as an inadequate one - is subject to further revisions, modifications or improvements. Any interpretation of the sign is incomplete - it calls for further interpretations (by means of signs). This idea is particularly important in the context of cognitive semiotics as it reflects the dynamicity of meaning-making processes and stresses the fact that meaning emerges in the course of cognitive activity. Synechism or continuity of semiosis, in turn, reflects the nature of our mental states (beliefs). Just like each belief is subject to doubt and inquiry, each sign is subject to reinterpretation. In other words, the process of interpretation is continuous - it is understood as a chain of subsequent signs without either an absolute, "first" sign or an ultimate, "final" sign (cf. CP 7.337). The idea of synechism implies the holism of signs (and their interpretations): the Peircean sign can exist only as a part of $a$ system of signs. Any particular sign is necessarily an interpretation of a preceding one and - in turn - it gives rise to the next sign which interprets it.

In summary, the Peircean view on semiosis reflects the basic assumptions concerning meaning-making: it is fallible, it is dynamic, it can be characterized at various levels, it is grounded in specific cognitive capacities (to be able to see similarities, contiguities or to form habits). The most crucial feature of the cognitive semiotic view on meaning-making, the dynamicity of semiosis, has its "internal", intra-systemic sources - it stems from the unavoidable fallibility of the interpretation and synechism of signs (and is reflected by the phenomenon of unlimited semiosis). Although the process of interpretation is ultimately constrained (if not determined) by dynamic objects, what we can actually discover by means of semiosis is an immediate object. The immediate object is the (dynamical) object as it is represented by the sign.

\section{A cognitivist approach to Peircean semiosis}

The general idea of standard cognitive science (cognitivism, Cartesian cognitive science) was to elicit the structures and mechanisms responsible for the activity of an agent (her or his behaviour) in the presence of certain external stimuli as well as in the context of the internal organization of the mind. In line with the 
representational theory of the mind, these structures consist (at least partially) of representations, and mechanisms consist of manipulations of these structures. Cartesian cognitive science is crucially committed to a functionalist view on the mind. The idea of an internal, causal organization mediating between input and output is a tacit and common assumption of cognitivist approaches. ${ }^{16}$

As I argued elsewhere (Konderak 2016; 2018), standard cognitive science can contribute to cognitive semiotic research by means of so-called cognitive modelling - a basic method of standard cognitive science allowing for explanations and predictions. Although this cognitivist method cannot be - supposedly - applied at all the levels of the Semiotic Hierarchy, it can be useful - as I claim - in explanations of meaning-making at the levels of signs and language. In particular, cognitive modelling reflects the internal dynamicity of a semiotic system, dynamicity which is immanent to the semiotic system and is relatively independent of broader, external (evolutionary, developmental) factors. ${ }^{17}$ In an attempt to show the role of cognitivism in studies on meaning-making, I interpret the functioning of a cognitive model in terms of the Peircean view on semiosis.

A meaning-making subject is characterized in line with Fetzer's notion of a semiotic system, i.e. "a system that has the capacity to create or to utilise signs, where this capability may be either naturally produced or artificially contrived" (Fetzer 1990: 31; my emphasis, P. K.). The "capacity to create or to utilise signs", in turn, is understood in terms of the triadic Peircean theory of signs presented above. ${ }^{18}$ According to Fetzer (1988), any semiotic system must meet the so-called intrinsicality requirement: a sign must stand for something else for the system and not just for the external observer.

The Peircean approach to semiosis, focusing on systems of signs and their interpretations in terms of subsequent signs, seems to be particularly apt for the cognitive modelling of semiotic systems. In this context, certain restrictions or constraints on the class of possible semiotic systems are taken into account.

16 As Robert Harnish (2002: 5) suggests, such a view can be dubbed "the narrow conception of cognition". Drawing on a functionalist, representational theory of mind, researchers define cognition as a mental manipulation of mental representations. Manipulation is defined as the creation, transformation or deletion of representations. Representations, in turn, are understood as either symbols - physical entities distinguished on the basis of their shapes (symbolic approaches) - or as patterns of activations in artificial neural networks (connectionist approaches).

17 Winfried Nöth presents a similar view on the relationship between cognitive science and semiotics discussing "Models of Cognition as Models of Semiosis" (Nöth 1994: 9-13).

18 Although I interpret semiotic systems in terms of Peircean theory, in principle it is possible to apply alternative accounts. Perhaps the evaluation of alternative cognitive models can be used as an argument for one or another theory of signs. 
Specifically, semiotic systems should be able to differentiate between a sign-vehicle and its object (understood as an immediate object or a dynamical object: in line with the characteristics of a sign presented above). They should create an interpretation connecting these two phenomena (to implement the Peircean triadic view on signs). This interpretation should be susceptible to revision (i.e. the system should simulate the fallibility of following semiotic interpretations) and meaningmaking should be modelled as a dynamic process. Consequently, only selected cognitive models - capable of implementing the above requirements - can be applied in studies on semiotic systems. In addition, the cognitive architecture for semiotic processes should enable the treatment of a sign as a sign; in other words, the putative cognitive model should represent its activity at some meta-level where sign-using activity can also be an object of considerations. The next section presents the actual implementation of a semiotic system interpreted in terms of the Peircean view on signs.

My approach to cognitive modelling could be called a simulational study of meaning. This approach involves using functioning cognitive models to discover the properties of cognitive processes (especially, meaning-making processes). In particular, it allows the study of the dynamics of meaning-making in the context of various sign systems. The simulational approach attempts to suggest the specific processes which underlie semiotic activity. Simultaneously, it can be used to add precision to the meaning of such terms as 'representation', 'interpretation' (and 'reinterpretation'), 'synechism' or 'fallibilism. Cognitive architectures (Anderson 1983, 2007; Taatgen, Anderson 2008; Konderak 2016) are the most popular tool facilitating the creation of cognitive models of various cognitive activities. My own attempt to model the processes of semiosis explores the capabilities delivered by the GLAIR cognitive architecture. GLAIR (Grounded Layered Architecture with Integrated Reasoning) with SNePS (Semantic Network Processing System ${ }^{19}$ ) (Shapiro, Bona 2010) and the robotic interface snarpy ${ }^{20}$ as a knowledge representation formalism delivers a tool for modelling embodied agents which can act in real, virtual, or simulated environments containing other agents. Due to technical limitations, the actual version of the model works on linguistic signs

19 It is significant, that Peirce (1909) - in an attempt to improve his algebraic notation - proposed a graphic notation dubbed relational graphs (Sowa 1992). Later, these graphs were transformed into the so-called existential graphs. These graphs are considered the earliest version of assertional networks formalism and an important contribution to contemporary AI knowledge representation formalisms (cf. also Sowa 2011).

20 Snarpy (Campbell, Burhans 2006) is the framework for creating embodied computational agents. It allows the linking of a symbolic level implemented as a SNePS network to a Pyro (Python Robotics) robot. 
(interpreted as Peircean symbols). Specifically, parts of a text are typed on the keyboard and they are input data for an interpreting system. I used the books Alice in Wonderland and Through the Looking-Glass (Carroll 2006[1865, 1872]) as a source of input data. Excerpts are matched onto an initially programmed semantic network representing background knowledge. The initial setting of the model (consisting of a basic semantic network) has been tested in Natural Language Processing laboratories, where cognitive science students - using SNaLPS (natural language interface) - asked questions and tried to extend the semantic network with new information. I do not want to present all the details and features of the implementation - I limit myself to the presentation of these features which are crucial to the modelling of meaning-making.

First, the model "perceives" (receives information transformed by the sensory apparatus). In the discussed model, this process has been extremely simplified: I limited the capacities of the model to the analysis of statements typed on the keyboard. The input data are supposed to be potentially meaningful (i.e. the model is not exposed to meaningless data); more precisely, they are supposed to be interpreted as signs. The task of my model consists of interpretation of these input data in terms of some knowledge base. In Peircean terms, a word recognized in typed input can be interpreted as a representamen or sign-vehicle. In other words, the word can be considered as Peircean Firstness.

Let us assume that the model receives the statement "Alice is a girl" and attempts to interpret it in terms of its semantic network (Fig. 1). Natural language statements (words) are represented as nodes connected to the network by means of the LEX arc. Having detected the sign-vehicle, the model should relate it to its putative object - an entity or phenomenon in a world. In other words, the model should recognize the sign-vehicle as a sign of something. The GLAIR model interprets the word it receives as referring to some internal element, i.e. to an (immediate) object $^{21}$ as it is represented within a semantic network. Specifically, either the model finds a corresponding node in its semantic network (if there is such a node - when the model already "knows" THIS Alice) or it creates a new node connected in a way to the network (in the case in which the model did not "encounter" Alice earlier). The (immediate) object can be interpreted in Peircean terms as Secondness - the "reality" of the sign and the condition of the mediated access.

21 The GLAIR architecture seems to support the Peircean distinction between an immediate object - an object as represented by means of signs (i.e. a node in a semantic network), and a dynamical object - an object as it exists independently of a sign-user or any system of signs (an object which can excite a perceptual apparatus or can be influenced by the actions of a meaning-making agent). 


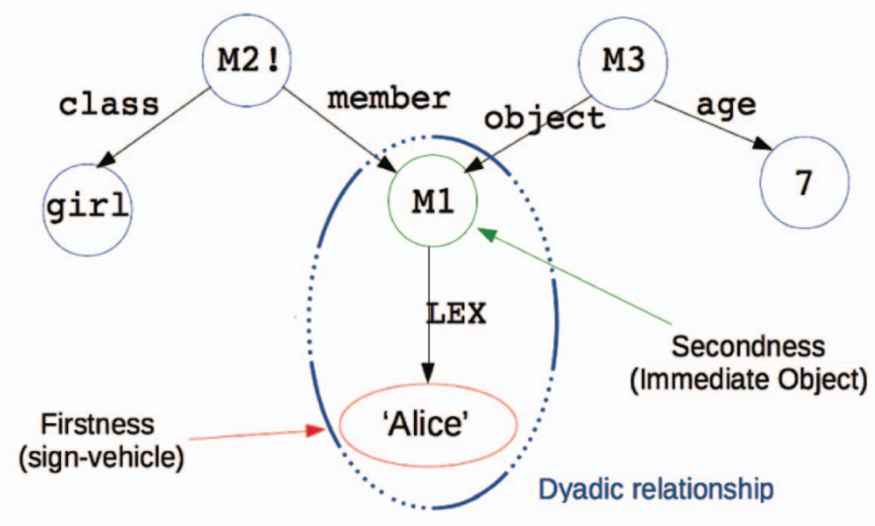

Figure 1. The model finds the node representing Alice (M1) and relates it to the signvehicle ('Alice').

These two steps (perceiving and relating to an internal node) provide dyadic relationships between sign-vehicles and their immediate objects. However, the relationship between a word (attached to a semantic network via the LEX node) and some other node (in this case, the node representing an object) is not sufficient for a sign relationship and, consequently, for the understanding of the utterance. The reason is that the meaning is not in an object (or the representing node) but emerges in the process of interpretation. In Peircean terms, it is the third element, an interpretant, that is crucial for semiosis. The meaning or interpretation of any word (sign) in GLAIR is the role of the object-node in a semantic network. In terms of the GLAIR model, the meaning of a sign is some part of the semantic network connected to the object-node. In our example (Fig. 2), the (limited) meaning of the word 'Alice' is constituted by connections between the node representing Alice (M1) and some part of the surrounding network: she is a girl (M2!), she is seven years old (M3), she followed the white rabbit (M5!). 


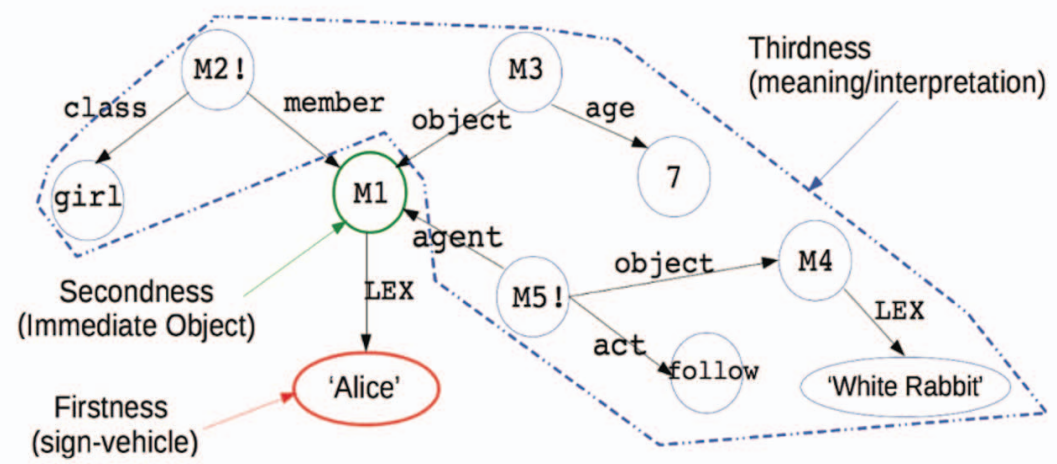

Figure 2. The meaning of the word 'Alice' is interpreted as (part of) a network connected to the node representing the object (M1).

In short, if the interpretant is the sense made of a sign (its meaning), it can be associated with the role of a node (interpreted as an immediate object) in a part of a network connected to this node. As the network is constantly changing (enlarging and changing its structure) as a result of new data, the meaning of any node is constantly reinterpreted. As a result, the functioning of such a model reflects the fallibility and dynamicity of meaning-making processes. Ultimately, the full meaning of the M1 node is the whole network connected to the M1 node. This statement clearly expresses a holistic approach to meaning.

The simple example presented above leads us to the conclusion that the GLAIR model can simulate the synechism of signs as well: each sign is necessarily an interpretation of the previous one and evokes the new (interpreting) one. Technically, to model interpretation of any sign, the system must relate it to an existing semantic network. In the specific case presented as Fig. 1, the system must represent objects which are girls to be able to interpret (i.e. relate to the existing knowledge base) the word 'Alice'.

The above model is limited to quasi-linguistic signs only due to the technical limitations of the GLAIR architecture and the bias of my own research. In principle, it is possible to design an interface which is capable of dealing with the visual data and combine it with a SNePS-like semantic network (cf. e.g. Klette 2014; Szeliski 2011). However, analysis of such a system would require reference to studies on the emergence of the capacity to interpret iconic signs (DeLoache, Burns 1994; Callaghan 1999). 


\section{Beyond cognitivism}

Functioning of the GLAIR-based model reflects (simulates) the first of the two aspects of meaning-making activity, namely an internal, intra-systemic one. The processes, as described above, cover just the dynamics of meaning-making inherent to the system. The role of external (in reference to the model) factors, the role of the interaction between a simulation of an agent and its environment (either real or simulated) are either ignored here or do not contribute to the explanation of the meaning-making activity. In a similar way, the simulated processes of meaning-making are relatively independent of the embodied/disembodied nature of an agent. More precisely, even if the agent is embodied, the bodily factors are internalized as with any other external factors. To use Mark Rowlands' (2010: 56-57) terminology, although meaning-making - as modelled by cognitivists - in a way depends on external factors, it is not constituted by them.

What seems to be most important in this context is that the explanation provided by a computational model is functional in nature. In other words, it is the role of a state in the network of input, output and other states which matters. Consequently, the phenomenal aspect of meaning-making activity is ignored (Chalmers 1995). In other words, meaning-making, understood as a series of reinterpretations driven by the rules of a system, is devoid of the phenomenal, experiential aspect.

Consequently, the notion of agency is seriously impoverished (see e.g. Tønnessen 2016), as the model simulates a representing and representations-processing agent. Such an agent is, in principle, passive: it just waits for incoming stimuli to process them in accordance with some set of rules. Additionally, such a simulation of an agent does not co-create its environment. The workings of the system are relatively independent of environmental factors.

However, when the first and the second levels of the Semiotic Hierarchy are considered, dynamic, embodied interaction with an environment and with other meaning-making subjects seems to be crucial. Meaning-making does not consist of rule-based operations on signs (symbols) but emerges out of mind-body-environment interactions. ${ }^{22}$ The capacity of a meaning-making subject to enact (to bring forth) her/his/its own domain of meaningful phenomena must be accounted for. Here, as argued above, an enactive-embodied cognitive science provides foundations for higher-level meaning-making.

\footnotetext{
22 It is - among others - Nöth who draws attention to the insufficiency of cognitivist accounts of semiosis: "Not all paradigms of the semiotic tradition are equally compatible with the views held by the cognitivists" (Nöth 1994: 8).
} 
Finally, the application of algorithm-based models always raises the question of the determination of the processes modelled and - at the methodological level of the predictability of the results of the functioning of a model. As semioticians note, unpredictability of human semiosis is a feature which cannot be neglected. ${ }^{23}$ The computational system presented above can be said to provide quasi-unpredictability. Each particular act of interpretation is a result of a number of factors, including the past experiences of a model. These experiences are reflected in the form of the weights of the connections between the nodes in a semantic network. To put it simply: the more often a word is encountered in a certain context, the higher is the value of the weight of the connection in the network. Consequently, a semiotician having access to the whole history of interactions and interpretations would be able to predict the result of subsequent meaning-making activities. We, as observers, cannot have such access, however. Consequently, from our point of view, it is difficult to predict a particular act of interpretation. It is important to note that we also face a similar situation in the case of Van Gelder's dynamic systems theory: differential laws allow predicting (with a degree of certainty) the behaviour of a meaning-making system. In other words, from the point of view of an enactive cognitive scientist, meaning-making is also quasi-unpredictable.

To sum up the above sections: it seems that neither cognitivism, as an allembracing theory of mind and cognition, nor autopoietic embodied enactivism, considered as a theory of cognition as a whole (De Jesus 2016: 131), can account for meaning-making in its various forms. Rather, it seems that these two approaches to cognition are complementary and necessarily intertwined in accounts of meaningmaking at various levels of the Semiotic Hierarchy framework.

\section{Connecting the approaches, connecting the levels}

The considerations so far may suggest that explanations of meaning-making processes and the subsequent predictions of meaning-making activities are irrevocably separated into cognitivist and $4 \mathrm{e}$ approaches. Is there any prospect of integrating the two cognitive views on meaning-making? Are we doomed to the unavoidable bifurcation in cognitive semiotic studies between functional-cognitivist and phenomenological-enactive approaches?

23 This feature is highlighted by e.g. Lotman (2009: 123): "Each time we speak of unpredictability we have in mind a specific collection of equally probable possibilities from which only one may be realised. In this way, each structural position represents a cluster of variant possibilities." This has been quoted and commented on in Semenenko 2012: 68; I am grateful to Aleksei Semenenko for drawing my attention to this aspect. 
As I have argued elsewhere (Konderak 2018), the two approaches may be treated as complementary. On the one hand, it would be unreasonable to claim that cognitivist approaches can account for meaning-making in its richness (pace Shapiro, Bona 2009). On the other hand, attempts to limit meaning-making just to phenomenological and enactive accounts seem to be somehow artificial (pace Zlatev 2018; cf. e.g. Chalmers 1995 on consciousness).

Let me first note that the above alternative (cognitivism - 4e cognitive science) is a fallacious one. $4 \mathrm{e}$ approaches to cognitive science cannot be treated as aniform stance. What is common to these approaches is the rejection of one or more aspects of standard cognitive science: the internal character of cognitive processes, the radical separation of the body and the world, symbolic representations or representations in general, computation as the main cognitive mechanism, etc. These four approaches may be combined in various ways, but there is also a tension between them or rather between interpretations of these approaches (cf. Rowlands 2010 on the various possible combinations of e's). Moreover, the label 'enactivism' embraces several differing approaches, so it is difficult to provide one consistent set of characteristics. Clearly, enactivism is based on a number of notions, such as autonomy, action, sensorimotor patterns, self-organization, sense-making, anti-representationalism, agency, emergence, embodiment, but the above notions are spread across the approaches - various scholars adapt and highlight various ideas. In some cases, enactivists adapt incompatible or even contradictory views on aspects of meaning-making activities (e.g. Noë 2004 vs. Hutto, Myin 2012). As a result, we should discuss enactivisms rather than one, uniform approach (cf. Nowakowski, Komendziński 2014: 12; Konderak 2018: 160-163). Similar remarks can be formulated in reference to embodied approaches (cf. Wilson 2002 for an overview of embodied approaches). In this context, one should look for attempts at reconciling tensions between approaches. The problem, as I see it, consists not only in combining representational cognitive science and the anti-representational non-standard approach to cognition and meaning-making. The problem is how to combine various enactivisms with embodied, extended and embedded approaches in their various interpretations. How to interpret, for instance, anti-representationalism presented by Hutto and Myin in their statement that "some cognitive activity - plausibly, that associated with and dependent upon the mastery of language - surely involves content" (Hutto, Myin 2012: xviii)? How to apply such views to various levels in the Semiotic Hierarchy?

The only serious and consistent attempt that I am aware of that tries to reconcile the standard approach to cognition and a number of non-standard ones is Rowlands' idea of an Amalgamated Mind. Instead of drawing sharp borderlines between the two lines of thinking about cognition presented above, Rowlands 
tries to include as much as possible from standard cognitive science with simultaneous appreciation of the phenomenological tradition. Consequently, Rowlands' approach combines ideas present in both traditions: information processing, representations, embodiment, agency and consciousness. Although Rowlands focuses on cognitive processes in general, it is easy to adapt his view to the needs of cognitive semiotic inquiries on meaning-making processes (semiosis).

The basic anti-Cartesian assumption of the Amalgamated Mind view is that one can neither enclose meaning-making processes in the skull (they are not exclusively internal) nor treat meaning-making processes as environmental ones (exclusively external). ${ }^{24}$ Instead, meaning-making processes can be characterized as combinations (amalgams) of neural processes, bodily processes and environmental processes. It is important to notice that in Rowlands' view, neural processes are an indispensable and non-eliminable element of cognitive processes. In this sense, internal processes are treated as a core of cognition. This general idea of meaningmaking can be further elaborated. Any cognitive process (including meaning-making processes) involves operations on information-bearing structures. Such structures can be internal (like the symbol M1 representing Alice in the semantic network presented in Section 6, above), but they can be bodily or external as well (e.g. actual inscriptions on a piece of paper or knots). Meaning-making consists (partially) of performing operations on these structures. Consequently, these processes can be internal (calculations in the head) or external (as a child counting pencils or pears). The main goal (in fact, the proper function ${ }^{25}$ ) of these operations is to transform these structures from being merely present (in the brain, in the body, in the environment) to available to subsequent processes (at the subpersonal level) or to the meaning-making subject (at the personal level; cf. Rowlands 2010: 144-147).

The discussed operations on information-bearing structures are made available by means of representational states created in the subject of the meaning-making process. In other words, amalgamated meaning-making processes are impossible without some kind of representation. ${ }^{26}$ This condition clearly satisfies representationalists.

24 This statement seems to be in line with the so-called biosemiotics enactivism: "As we saw a sign is not something internal but nor is it a 'ready-made' external object either" (De Jesus 2016: 142).

25 A proper function (Millikan 1984) of a meaning-making process reflects what that process is supposed to do or what it is designed for. The reference to proper function is necessary because processes may have various functions, they may malfunction, and they can be a part of a network of functions.

26 The reference to representations seems to separate the Amalgamated Mind approach from radically enactivist stances (e.g. Hutto, Myin 2012). However, as Rowlands (2010: 114) argues, such separation or incompatibility may be only apparent, as the criterion of the cognitive is 
Finally, to do justice to the phenomenological aspect of meaning-making, Rowlands formulates the ownership condition: meaning-making processes belong to a subject of relevant representational states. To put it differently, any process that counts as semiosis must belong to a "person", which is understood as "an organism capable of detecting changes in its environment and modifying its behaviour accordingly" (Rowlands 2010: 146). For a process to count as meaningmaking, there must be an owner, a subject which has authority over the process.

The claim that there are no subject-less meaning-making processes introduces a phenomenological dimension into studies on meaning-making activities, namely the ownership condition. This condition - in the case of personal-level processes is based on the notion of intentionality as a disclosing activity: a meaning-making process is owned by a subject if it discloses (reveals) the world to the subject. One last step is necessary to establish the ownership condition. It consists of the statement that the mineness of experience is built into the very notion of experience; in Rowlands' own words "it is part of what it is like to have it" (Rowlands 2010: 215). When we consider the phenomenological character of experience, we will also discover - apart from qualitative characteristics, what-it-is-like-ness - the possessive aspect, the mineness mentioned above. Additionally, the ownership condition addresses the problem - discussed above - raised by enactive cognitive science, namely the problem of agency.

To sum up the Amalgamated Mind approach: to answer the question how to account for meaning-making and how to predict consecutive meaning-making activities, researchers have to consider two types of criteria. The first type refers to information-bearing structures (either internal, bodily, or external), making information available to a meaning-making subject and the production of representational states. The second type is based on the phenomenology of meaningmaking and it invokes ownership understood as the mineness of experiences. The embodiedness and extendedness of meaning-making processes are obvious consequences of this formulation.

The Amalgamated Mind view acknowledges the diversity of meaning-making activities, reflecting the hierarchical structure of the Semiotic Hierarchy. In particular, the approach emphasizes the role of embodiment and situatedness of a meaning-making subject. The diversity of information-bearing structures and operations on these structures forces us to accept the multi-layered nature of meaning-making (mental, embodied, situated). Although the approach retains some conceptual analyses of cognitivism - in particular, it acknowledges the role

based on sufficient conditions. In other words, it is possible that there are other meaningmaking processes which do not involve representations, like perceptual meaning-making as presented by Gibson. 
of representations and operations on representations (reflected in the Peircean view on semiosis) - it also introduces notions crucial for the enactive or embodied approaches to cognition and meaning-making (agency, consciousness, among others).

Third, the Amalgamated Mind view embraces internal processes on internal representations as well as bodily and environmental structures and processes. Meaning-making processes create a spectrum of phenomena - from internal ones to embodied ones and to amalgams of neural, bodily and environmental processes. In the dependence of the particular process discussed, the proportions of these three aspects may differ. There are processes which are primarily internal ones, but there are also processes which crucially involve external (environmental) structures and processes. These proportions reflect the relative role of the internal and external aspects of semiosis in actual cognitive - meaning-making - activities.

\section{Conclusion}

Cognitive semiotics addresses the problem of explaining dynamic meaningmaking processes and predicting the behaviour of meaning-making subjects. Explanations require reference to particular theoretical frameworks. In an attempt to provide a methodological basis for such studies, cognitive semiotics reaches to both semiotics and cognitive science. The problem, as discussed in the present paper, concerns the actual cognitive basis of semiosis - in both its external and internal aspects. In an attempt to resolve this problem, it is necessary to separate semiotic and non-semiotic phenomena. Establishment of the "lower semiotic threshold" as well as specification of putative higher thresholds and levels of semiosis is of crucial importance here. Given the multiplicity of proposals, one has to make a more or less arbitrary choice. The Semiotic Hierarchy framework adapted in the paper - not only unifies (to a degree) phenomenological, semiotic, linguistic, cognitive scientific, and evolutionary approaches, but is declared to be "[a] significant common ground for further theoretical and empirical investigations" (Zlatev 2009: 179).

Accepting this framework as a basis of considerations on meaning-making activities, I discuss the putative cognitive underpinnings of semiosis at various levels of the Semiotic Hierarchy. As I argue, an enactive approach seems to account for meaning-making phenomena at the first level, an embodied approach - in addition to enactive one - accounts for experiential meaning-making at the second level. Both embodiment and enaction provide a foundation for subsequent levels; in particular, they may lead to the emergence of a subject's capacity 
to represent. This capacity results in semiosis in the narrow sense - the ability to use indexical, iconic and symbolic signs as well as the systems of such signs. However, I would like to stress that cognitive mechanisms underpinning lower levels do not lose their validity at the higher levels. Consequently, for instance, to account for pantomime (Zlatev, Żywiczyński, Wacewicz 2020) in the context of meaning-making activities, one has to refer to both "external" factors (enacted activities, embodied imitation) and "internal" factors (e.g. systematic relationships between gestures).

At this juncture, one may wonder whether cognitivism and the competing $4 \mathrm{e}$ approaches can be combined within one theory to account for meaning-making in its diversity. Perhaps we are doomed, as Clark and Toribio (1994) suggest, to an unavoidable "division of labour" of a kind: some aspects of cognition (and meaning-making) can be addressed by $4 \mathrm{e}$ approaches, other aspects require explanations in cognitivist terms. From the point of view of a philosopher of cognitive science, the basic question is whether it is possible to integrate the two alternative cognitive accounts discussed above. On the one hand, Van Gelder's dynamical systems approach (Van Gelder 1995; cf. also Thompson 2007) can account for semiosis resulting from the engagement of an embodied subject with his/her/its environment. On the other hand, cognitive modelling, as a cognitivist method, can account for aspects of the intra-systemic processes of Peircean interpretation and reinterpretation. The very possibility of integration would bring us closer to a uniform cognitive semiotic theory of meaning-making.

As the Amalgamated Mind approach shows, the rapprochement of the enactive/embodied view on meaning-making and the cognitivist perspective is not an unrealistic or utopian prospect. A careful specification of such notions as organism-environment interaction, embodiment, representation (embracing external, embodied as well as internal representations), operations on representations, agency or consciousness allows - as Rowlands argues - for a consistent specification of cognition which does justice to both lines of thinking about cognition. In particular, Rowlands' idea of a meaning-making system as an amalgam of "neural structures and processes, bodily structures and processes, and environmental structures and processes" (Rowlands 2010: 83) seems to be on the right track. This approach, adapted to the needs of the cognitive semiotic, facilitates explanations of both the "internal" and "external" aspects of meaning-making. Definitely, Rowlands' approach requires a detailed elaboration in the context of meaningmaking processes. The development of such an attempt to unify approaches to cognition is one of the main challenges for cognitive semiotic research in the near future. 
In closing, I want to stress that the proposal presented in the paper still seems to be a combination of two lines of thinking about meaning-making rather than a consistent composition. ${ }^{27}$ However, as I argue, the above remark can be formulated in reference to enactive or embodied approaches - diversity is still threatening. I hope that I have shown that the combination presented can be - gradually, step by step - transformed into a composition.

\section{References}

Alrøe, Hugo 2016. Three levels of semiosis: Three kinds of kinds. Cybernetics and Human Knowing 23(2): 23-38.

Anderson, John 1983. The Architecture of Cognition. Cambridge: Harvard University Press. Anderson, John 2007. How Can the Human Mind Occur in the Physical Universe? New York: Oxford University Press. https://doi.org/10.1093/acprof:oso/9780195324259. 001.0001/acprof-9780195324259

Bertalanffy, Ludwig von 1968. General System Theory: Foundations, Development, Applications. New York: George Braziller.

Callaghan, Tara 1999. Early understanding and production of graphic symbols. Child Development 70(6): 1314-1324. https://doi.org/10.1111/1467-8624.00096

Cameron, William 2001. Autopoiesis, agency and accident: Criteria for the attribution of life. Systems Research and Behavioral Science 18: 447-459. https://doi.org/10.1002/ sres.355

Campbell, Alistair; Burhans, Debra 2006. A layered heterogeneous cognitive robotics architecture. In: Beetz, Michael; Rajan, Kanna; Thielscher, Michael; Rusu, Radu Bogdan (eds.), Cognitive Robotics: Papers from the AAAI Workshop (CogRob2006) Technical Report WS-06-03. Menlo Park: AAAI Press, 40-46.

Carroll, Lewis 2006[1865, 1871]. Alice Adventures in Wonderland \& Through the LookingGlass. (A Bantam Classic Book.) New York: Bantam Dell.

Chalmers, David 1995. Facing up to the problem of consciousness. Journal of Consciousness Studies 2: 200-219.

Clark, Andy 1998. Magic words: How language augments human computation. In: Carruthers, Peter; Boucher, Jill (eds.), Language and Thought: Interdisciplinary Themes. Cambridge: Cambridge University Press, 162-183. https://doi.org/10.1017/ CBO9780511597909.011

Clark, Andy 2008. Supersizing the Mind: Embodiment, Action, and Cognitive Extension. New York: Oxford University Press.

Clark, Andy; Chalmers, David 1998. The Extended Mind. Analysis 58: 10-23. https://doi. org/10.1093/analys/58.1.7

Clark, Andy; Toribio, Josefa 1994. Doing without representing? Synthese 101: 401-431. https://doi.org/10.1007/BF01063896

27 Ipso facto, I agree with the reviewer's critical remark that the approaches presented in this paper "seem to be combined, but not actually composed". 
CP $=$ Peirce, Charles S. 1931-1958.

Daddesio, Thomas 1995. On Minds and Symbols: The Relevance of Cognitive Science for Semiotics. Berlin: De Gruyter Mouton. https://doi.org/10.1515/9783110903003

Deacon, Terrence 1997. The Symbolic Species: The Co-Evolution of Language and the Brain. New York: Norton.

Deely, John 2001. Physiosemiosis in the semiotic spiral: A play of musement. Sign Systems Studies 29(1): 27-48.

De Jesus, Paulo 2016. From enactive phenomenology to biosemiotics enactivism. Adaptive Behavior 24(2): 130-146. https://doi.org/10.1177/1059712316636437

DeLoache, Judy S.; Burns Nancy M. 1994. Early understanding of the representational function of pictures. Cognition 52: 83-110. https://doi.org/10.1016/00100277(94)90063-9

Donald, Merlin 1991. Origins of the Modern Mind: Three Stages in the Evolution of Culture and Cognition. Cambridge: Harvard University Press.

Eco, Umberto 1976. A Theory of Semiotics. Bloomington: Indiana University Press. https:// doi.org/10.1007/978-1-349-15849-2

Fetzer, James 1988. Signs and minds: An introduction to the theory of semiotic systems. In: Fetzer, James (ed.), Aspects of Artificial Intelligence. Dordrecht: Kluwer, 133-161. https://doi.org/10.1007/978-94-009-2699-8_5

Fetzer, James 1990. Artificial Intelligence: Its Scope and Limits. Dordrecht: Kluwer Academic Publishers. https://doi.org/10.1007/978-94-009-1900-6

Gallagher, Shaun 2007. The natural philosophy of agency. Philosophy Compass 2(2): 347357. https://doi.org/10.1111/j.1747-9991.2007.00067.x

Gallagher, Shaun; Zahavi, Dan 2008. The Phenomenological Mind: An Introduction to Philosophy of Mind and Cognitive Science. Milton Park: Routledge.

Gibson, James J. 1979. The Ecological Approach to Visual Perception. Boston: Houghton Mifflin.

Harnish, Robert 2002. Minds, Brains, Computers: An Historical Introduction to the Foundations of Cognitive Science. Malden, Oxford: Blackwell Publishers.

Heil, John 2004. Philosophy of Mind: A Guide and Anthology. Oxford: Oxford University Press. https://doi.org/10.4324/9780203506455

Hutto, Daniel; Myin, Erik 2012. Radicalizing Enactivism: Basic Minds without Content. Cambridge: The MIT Press. https://doi.org/10.7551/mitpress/9780262018548.001.0001 Itkonen, Esa 2003. What is Language? Turku: Turku University Press.

Klette, Reinhard 2014. Concise Computer Vision. London: Springer. https://doi.org/10. 1007/978-1-4471-6320-6

Koch, Walter A. 1987. A plea for evolutionary cultural semiotics. In: Escbach, Achim; Koch, Walter A. (eds.), A Plea for Cultural Semiotics. Bochum: Brockmeyer, 53-131.

Konderak, Piotr 2016. On evolution of thinking about semiosis: Semiotics meets cognitive science. Avant 7(2) (Polish Cognitive Science): 82-103. https://doi.org/10.26913/ 70202016.0112 .0005

Konderak, Piotr 2018. Mind, Cognition, Semiosis: Ways to Cognitive Semiotics. Lublin: Maria Curie-Sklodowska University Press.

Krampen, Martin 1981. Phytosemiotics. Semiotica 36(3/4): 187-209. https://doi.org/10. 1515/semi.1981.36.3-4.187 
Kull, Kalevi 2005. Semiosphere and a dual ecology: Paradoxes of communication. Sign Systems Studies 33(1): 175-189.

Kull, Kalevi 2009. Vegetative, animal and cultural semiosis: The semiotic threshold zones. Cognitive Semiotics 4(4): 8-27. https://doi.org/10.1515/cogsem.2009.4.spring2009.8

Lotman, Juri M. 2005. On the semiosphere. Sign Systems Studies 33(1): 205-229.

Lotman, Juri M. 2009. Culture and Explosion. (Clark, Wilma, trans.; Grishakova, Marina, ed.) Berlin: Mouton de Gruyter.

Maturana, Humberto R. 1970. Biology of Cognition: Biological Computer Laboratory Research Report BCL 9.0. Urbana: University of Illinois.

McCune, Lorraine 2016. Meaning, consciousness and the onset of language, In: Zlatev, Jordan; Sonesson, Göran; Konderak, Piotr (eds.), Meaning, Mind and Communication: Explorations in Cognitive Semiotics. Frankfurt am Main: Peter Lang, 127-133.

Merleau-Ponty, Maurice 1962. Phenomenology of Perception. London: Routledge \& Kegan Paul.

Millikan, Ruth 1984. Language, Thought, and Other Biological Categories. Cambridge: The MIT Press.

Noë, Alva 2004. Action in Perception. Cambridge: The MIT Press

Nowakowski, Przemysław; Komendziński, Tomasz 2014. Cognition as shaking hands with the world: Introduction. Avant 5(2): 10-16. https://doi.org/10.26913/50202014. 0109.0001

Nöth, Winfried 1994. Semiotic foundations of the cognitive paradigm. Semiosis 73(1): 5-16.

Nöth, Winfried 2000. Umberto Eco's semiotic threshold. Sign Systems Studies 28: 49-61.

Nöth, Winfried 2001. Protosemiotics and physicosemiotics. Sign System Studies 29(1): 13-25.

Peirce, Charles S. 1931-1958. Collected Papers of Charles Sanders Peirce. (Vols. 1-6, Hartshorne, Charles; Weiss, Paul, eds., 1931-1935; vols. 7-8, Burks, Arthur W., ed., 1958.) Cambridge: Harvard University Press. [In-text references are to CP, followed by volume and paragraph numbers.]

Pelc, Jerzy 2013. Dwa pojęcia komunikacji [Two notions of communication]. Studia Semiotyczne [Semiotic Studies] 28/29: 107-119.

Pérez, Carlos A. 2016. Mutual enlightenment: A phenomenological interpretation of the Embodied Simulation Hypothesis. In: Zlatev, Jordan; Sonesson, Göran; Konderak, Piotr (eds.), Meaning, Mind and Communication: Explorations in Cognitive Semiotics. Frankfurt am Main: Peter Lang, 31-45.

Piaget, Jean 1962. Play, Dreams and Imitation in Childhood. New York: Norton.

Rodríguez Higuera, Claudio J.; Kull, Kalevi 2017. The Biosemiotic Glossary Project: The semiotic threshold. Biosemiotics 10: 109-126. https://doi.org/10.1007/s12304-0179289-4

Rowlands, Mark 2010. The New Science of Mind: From Extended Mind to Embodied Phenomenology. Cambridge: The MIT Press. https://doi.org/10.7551/mitpress/ 9780262014557.001 .0001

Saussure, Ferdinand de 1959. Course in General Linguistics. (Baskin, Wade, trans.; Bally, Charles; Sechehaye, Albert, eds.) New York: The Philosophical Society. 
Sebeok, Thomas A. 1963. Communication among social bees; Porpoises and sonar; Man and dolphin. Review article. Language 39, 448-66. https://doi.org/10.2307/411126

Sebeok, Thomas A. 1986. I Think I Am a Verb: More Contributions to the Doctrine of Signs. New York: Springer Science+Business Media. https://doi.org/10.1007/978-1-48993490-1

Semenenko, Aleksei 2012. The Texture of Culture: An Introduction to Yuri Lotman's Semiotic Theory. New York: Palgrave Macmillan. https://doi.org/10.1057/9781137008541_1

Shapiro, Stuart; Bona, Jonathan 2009. The GLAIR Cognitive Architecture. In: Biologically Inspired Cognitive Architectures. Menlo Park: AAAI Press, 141-152.

Sonesson, Göran 2007. From the meaning of embodiment to the embodiment of meaning: A study in phenomenological semiotics. In: Ziemke, Tom; Zlatev, Jordan; Frank, Roslyn, M. (eds.), Body, Language and Mind. Vol. 1: Embodiment. Berlin, New York: Mouton de Gruyter, 85-128.

Sonesson, Göran 2009. The view from Husserl's lectern: Considerations on the role of phenomenology in cognitive semiotics. Cybernetics and Human Knowing 16(3/4): 107-148. https://doi.org/10.3726/81608_133

Sowa, John F. 1992. Semantic networks. In: Shapiro, Stuart (ed.), Encyclopedia of Artificial Intelligence (2nd ed.). New York: Wiley-Interscience.

Sowa, John F. 2011. Peirce's tutorial on existential graphs. Semiotica 186: 1-4, 345-394. https://doi.org/10.1515/semi.2011.060

Stjernfelt, Frederik 2003. Sebeotics at the threshold: Reflections around a brief Sebeok introduction. Semiotica 147(1/4): 485-494. https://doi.org/10.1515/semi.2003.105

Szeliski, Richard 2011. Computer Vision: Algorithms and Applications. London: SpringerVerlag. https://doi.org/10.1007/978-1-84882-935-0

Taatgen, Niels A.; Anderson, John 2008. Constraints in cognitive architectures. In: Sun, Ron (ed.), The Cambridge Handbook of Computational Psychology. Cambridge: Cambridge University Press, 170-185. https://doi.org/10.1017/CBO9780511816772.009

Thompson, Evan 2007. Mind in Life: Biology, Phenomenology and the Sciences of Mind. London: Belknap Press.

Thompson, Evan; Stapleton, Mog 2009. Making-sense of sense-making: Reflections on enactive and extended mind theories. Topoi 28(1): 23-30. https://doi.org/10.1007/ s11245-008-9043-2

Tomasello, Michel 2008. Origins of Human Communication. Cambridge: The MIT Press. https://doi.org/10.7551/mitpress/7551.001.0001

Tønnessen, Morten 2016. Agency in biosemiotics and enactivism. In: Zlatev, Jordan; Sonesson, Göran; Konderak, Piotr (eds.), Meaning, Mind and Communication: Explorations in Cognitive Semiotics. Frankfurt am Main: Peter Lang, 69-82.

Tønnessen, Morten; Beever, Jonathan 2014. Beyond sentience: Biosemiotics as foundation for animal and environmental ethics. In: Hadley, John; Aaltola, Elisa (eds.), Animal Ethics and Philosophy: Questioning the Orthodoxy. London: Rowman \& Littlefield International, 47-62.

Uexküll, Jakob von 1957. A stroll through the worlds of animals and men. In: Schiller, Claire (ed., transl.), Instinctive Behavior: The Development of a Modern Concept. New York: International Universities Press, 5-80. 
Uexküll, Jakob von 1982. The theory of meaning. Semiotica 42(1): 25-82. https://doi. org/10.1515/semi.1982.42.1.25

Van Gelder, Tim 1995. What might cognition be, if not computation? The Journal of Philosophy 92(7): 345-381. https://doi.org/10.2307/2941061

Varela, Francisco J.; Thompson, Evan; Rosch, Eleanor 1991. The Embodied Mind: Cognitive Science and Human Experience. Cambridge: The MIT Press. https://doi.org/10.7551/ mitpress/6730.001.0001

Wilson, Margaret 2002. Six views on embodied cognition. Psychonomic Bulletin \& Review 9(4): 625-636. https://doi.org/10.3758/BF03196322

Zlatev, Jordan 2007. Embodiment, language and mimesis. In: Ziemke, Tom; Zlatev, Jordan; Franck, Roslin M. (eds.), Body, Language, Mind. Vol. 1: Embodiment. Berlin, New York: Mouton de Gruyter, 297-337.

Zlatev, Jordan 2009. The Semiotic Hierarchy: Life, consciousness, signs and language. Cognitive Semiotics 4: 169-200. https://doi.org/10.1515/cogsem.2009.4.spring2009.169

Zlatev, Jordan 2018. Meaning making from life to language: The Semiotic Hierarchy and phenomenology. Cognitive Semiotics 11(1). https://doi.org/10.1515/cogsem-2018-0001

Zlatev, Jordan; Sonesson, Göran; Konderak, Piotr 2016. Introduction: Cognitive semiotics comes of age. In: Zlatev, Jordan; Sonesson, Göran; Konderak, Piotr (eds.), Meaning, Mind and Communication: Explorations in Cognitive Semiotics. Frankfurt am Main: Peter Lang, 9-30. https://doi.org/10.3726/978-3-653-04948-0

Zlatev, Jordan; Żywiczyński, Przemysław; Wacewicz, Sławomir 2020. Pantomime as the original human-specific communicative system. Journal of Language Evolution 5(2), 156-174. https://doi.org/10.1093/jole/lzaa006

\section{К интеграции двух аспектов семиозиса (с точки зрения когнитивной семиотики)}

Смыслообразующие процессы, понимаемые иерархически, в соответствии с концепцией «семиотической иерархии», изменяются на различных временных отрезках. Чтобы объяснить и предсказать эти изменения, в статье описывается когнитивный подход к семиозису. Такой интердисциплинарный подход, сочетающий семиотические и когнитивные исследования позволяет предсказать направление семиозиса. В этом контексте активный процесс смыслопорождения рассматривается с точки зрения как «внешних» (по отношению к семиотической системе), так и «внутренних» факторов. Кроме того, показывается, каким образом с помощью терминов когнитивной теории должны быть сформулированы как «внешние», так и «внутренние» источники динамики смыслообразующей деятельности.

Статья описывает нестандартный «4Е»-подход к смыслообразованию. Согласно этому подходу, смыслопорождающие процессы формируются (а не просто зависят) под воздействием окружающей среды, а также организма. Динамичность семиозиса может быть объяснена в терминах познающего, воплощенного субъекта (агента), который воплощает в жизнь свою собственную сферу значимых явлений. Именно эта точка зрения на смыслопорождение является когнитивной основой первых двух уровней семиотической иерархии. 
В следующих разделах излагаются взгляды Пирса на знаки и семиозис, согласно которым семиозис является результатом самой природы знака и знаковой системы. С этой точки зрения, в динамике семиозиса первичными являются «внутренние» источники: она вытекает из неизбежной ошибки интерпретации и синехизма знаков. Статья демонстрирует, что и к этому аспекту семиозиса применимы средства когнитивной науки и когнитивное моделирование.

На основе идеи Роулендса об объединенном разуме (Amalgamated Mind) в заключении выдвигается предложение разработать единый когнитивный подход, позволяющий интегрировать вышеупомянутые аспекты семиозиса.

\section{Semioosi kahe aspekti lõimimise poole - kognitiivsemiootiline vaatenurk}

Mõistetuna hierarhiliselt, kooskõlas semiootilise hierarhia raamistikuga, muutuvad tähendusloome protsessid mitmes ajamõõtkavas. Nende muutuste selgitamiseks ning ennustamiseks võib semioosi vaadelda kognitiivsest vaatepunktist. Kasutan interdistsiplinaarset lähenemist, mis ühendab semiootika- ja kognitiivuuringud, ning püüan selgitada tähendusloometegevust ja ennustada semioosi kulgu. Selles kontekstis vaatlen tegevusloometegevust nii (semiootilise süsteemi) "väliste" kui ka "sisemiste" tegurite kujundatuna. Samuti näitan, kuidas tähendusloome dünaamika nii "väliseid" kui ka "sisemisi” allikaid tuleks esitada kognitsiooniuuringute terminites.

Alustan mittestandardse (4e) lähenemisega tähendusloomele. Selle raamistuse kohaselt moodustuvad tähendusloomeprotsessid kehalistest ja keskkonnateguritest (mitte üksnes ei sõltu neist). Semioosi dünaamilisust saab selgitada kogeva, kehastunud subjekti (toimija) terminites, kes viib ellu omaenda tähenduslike nähtuste valdkonda. Väidan, et see vaatenurk tähendusloomele on semiootilise hierarhia esimese kahe tasandi kognitiivseks aluseks.

Järgmistes osades esitan peirce'iliku vaate märkidele ja semioosile, mille kohaselt tuleneb semioos märgi ja märgisüsteemi olemusest. Vastavalt sellele on semioosi dünaamilisusel esmased "sisemised" allikad: see võrsub tõlgenduse paratamatust ja märkide sünekismist. Näitan, et semioosi sellele aspektile saab läheneda standardse (kognitivistliku) kognitiivteaduse vahenditega ning kognitiivse modelleerimise abil.

Viimaks visandan ettepaneku proovida töötada välja ühtset kognitiivset raamistust, mis võimaldab semioosi eespoolmainitud aspekte lõimida ning põhineb Rowlandsi ühendatud meele (Amalgamated Mind) ideel. 